\title{
Ikaskuntza Zerbitzuan oinarritutako Gradu Amaierako Lanen azterketa, ikasleen identitate hezitzailea eraikitzeko eskaintzen dituzten aukerak
}

\author{
Analyse of Final Degree Projects based on Service-Learning, with the aim of \\ identifying the opportunities provided for the Professional identity construction
}

\author{
Elena López-de-Arana*, Itxaso Sáenz-de-la-Fuente, Maitane Prol, Irati Fernández \\ Hezkuntza eta Kirol Fakultatea \\ $\mathrm{UPV} / \mathrm{EHU}$
}

LABURPENA: Nazio Batuen Garapen Iraunkorrerako 2030 Agendan zehaztutako mugarrien lorpenerako, Unibertsitate Hezkuntzak erantzukizuna du. Hezitzaileen Formakuntzan, Ikaskuntza Zerbitzua irakaskuntza metodo egokitzat hartu izan da helburu horiek errealitate bilaka daitezen. Lan honetan, aztergai izan diren zerbitzuak Ramon Bajo eskolan aurrera eraman dira, helburua ondorengoa izanik: ezagutzea Ikaskuntza Zerbitzuan oinarritutako Gradu Amaierako Lanak burutu dituzten ikasleek izandako bizipenak eta horiek euren identitate hezitzailearen eraikuntzan izan duten efektua. Parte hartu duten 3 ikasleen istorioak gauzatutako eduki analisitik azaleratu diren 4 kategorien arabera antolatu dira: norberaren buruaren inguruko balorazioa, tutoretza prozesuaren balorazioa, ikastetxean izandako bizipenen balorazioa, eta Ikaskuntza Zerbitzuaren inguruko balorazioa. Agertutako emaitzetatik ondorioztatu daiteke Ikaskuntza Zerbitzuan oinarritutako Gradu Amaierako Lanei esker ikasleek hainbat konpetentzien garapena aitortzen dutela, lankidetzaren garrantziaz jabetu direla, eta autoestimua indartu egin dela bai ikasitakoaren funtzionalitateagatik, bai erronka pertsonalak gainditzeko aukera izan dutelako. Azkenik, hobetzekoak identifikatzen dira, ikasleen prozesuan oztopo izan diren elementuak oinarritzat hartuz.

GAKO-HITZAK: ikaskuntza zerbitzua, unibertsitate hezkuntza, hezitzaileen formakuntza, identitate hezitzailea, lankidetza, autoestimua

ABSTRACT: Higher Education is responsible in achieving the milestones specified in the 2030 Agenda for Sustainable Development, approved by the General Assembly of the United Nations. During Teacher Education, it seems that Service-Learning is an appropriate teaching method to make these objectives come true. In this work, we analyse the services that have been carried out in Ramon Bajo School, with the objective of knowing the experiences, and their effects on the professional identity development of the students who have developed their Final Degree Projects through Service-Learning. The 3 participants' narratives have been organized into 4 categories that emerge from content analysis carried out: one self's assessment, tutoring's assessment, School experience's assessment, and Service-Learning's assessment. The results suggest that Final Degree Projects based on Service-Learning favour the perception about the development of certain skills, the awareness of cooperation's importance, and the self-esteem strengthening both for the functionality of what has been learned, and for the opportunity to face personal challenges. Finally, some improvements are specified, identifying the elements that have hindered the students' process.

KEYWORDS: service-learning, higher education, teacher education, professional identity, cooperation, self-esteem

\footnotetext{
* Harremanetan jartzeko / Corresponding author: Elena López-de-Arana. UPV/EHU. Didaktika eta Eskola Antolakuntza Saila. Hezkuntza eta Kirol Faultatea. Juan Ibáñez de Sto. Domingo, 1. 01006 Vitoria-Gasteiz. elena.lopezdearana@ehu.eus - https:// orcid.org/0000-0002-6962-5469

Nola aipatu / How to cite: López-de-Arana, Elena; Sáenz-de-la-Fuente, Itxaso; Prol, Maitane; Fernández, Irati. (2019). «lkaskuntza Zerbitzuan oinarritutako Gradu Amaierako Lanen azterketa, ikasleen identitate hezitzailea eraikitzeko eskaintzen dituzten aukerak identifikatuz»; Tantak, 31(1), 149-175. (https://doi.org/10.1387/tantak.20504).

Jasotze-data: 2019/01/08 Onartze-data: 2019/03/28.

ISSN 0214-9753 - elSSN 2444-3581 / (c) 2019 UPV/EHU
}

(c) (i) Obra hau Creative Commons Atribución 4.0 Internacional-en lizentziapean dago 


\section{IDENTITATE HEZITZAILEAREN ERAIKUNTZA ETA IKASKUNTZA ZERBITZUA}

Identitate hezitzailea konstruktu psikologikoa da. Edozein irakasleren praktikak aurreikuspena, azalpena eta ulermena ahalbideratzen duten ezaugarri pertsonal zein profesional propioei erreferentzia egiten die. Horren ondorioz, irakasleak bere burua errekonozitzeaz gain, besteek errekonozitua izateko aukera eskaintzen du (Gysling, 1992).

Autore gehienek azpimarratzen dute identitate hezitzailearen eraikuntza prozesu pertsonal zein kolektibo konplexu eta dinamikoaren ondorioa dela (Prieto, 2004). Definizio horrek bi alderdi uzten ditu agerian: norbanakotasuna eta testuingurua, hots, irakasle bakoitzaren eskolako dinamikak eta egiturak (Pardo \& Opazo, 2019). Identitate hezitzailearen kontzeptualizazio hau paradigma soziokulturaletik edo eraikitzailetik eratortzen da.

Alderdi kolektiboa irakasle bakoitzak bere buruaren inguruan eraiki duen irudikapen intersubjektiboa da (Prieto, 2004). Errepresentazio hauek irakasle taldean garatutako hausnarketa kritiko eta ongi oinarrituen ondorioa dira (Prieto, 2004). Prozesu hauek errazten dute inkontzienteak diren hainbat praktikaz ohartzea, eta diskurtsoaren eta praktikaren arteko inkongruentziak detektatzea (Cantón \& Tardif, 2018). Alderdi horrek aditzera ematen digu identitate hezitzailea, testuinguruaren mendean dagoenez, dinamikoa, aldakorra, eta konplexua dela.

Alderdi pertsonala irakasle bakoitzak bere buruaren inguruan eraiki duen irudikapen subjektiboa da (Prieto, 2004). Errepresentazio hauek biltzen dituzte irakasle bakoitzak - maila inkontzientea bada ere - dituen jarrerak, sinesmenak, eta balioak (Rodgers \& Scott, 2008; Vahasantanen \& Billet, 2008). Hauen araberakoa izango da irakasle horrek erakutsiko duen inplikazioa eta konpromisoa bete beharreko funtzioak gauzatzerakoan (Prieto, 2004).

Identitate hezitzailearen eraikuntza lan-bizitza osoan zehar garatzen den arren (Prieto, 2004), Ávalos-ek (2002) aldarrikatzen du irakasleen hasierako formakuntza momentu giltzarria dela lan honetan aritzeko.

Identitate hezitzailearen eraikuntzak Practicumarekin duen lotura aski frogatua dago (González, 2011; Tejada y Ruíz, 2013). Autoreen hitzetan, Practicumaren esperientziari esker eta haren inguruan egiten den hausnarketari esker, ikasleek hainbat konpetentzia garatzen dituzte. Konpetentzia horiek eta konpetentziok lortzeko partekatzen diren hausnarketek errazten dute identitate hezitzailearen eraikuntza. Norabide berean, beste autore batzuek Gradu Amaierako Lanekin lotu izan dute identitate hezitzailearen garapena (López-de-Arana, Rekondo \& Salegi, 2013). Eta azkenik, beste ikerketa batzuek identitate hezitzailearen garapena Ikaskuntza Zerbitzuarekin erlazionatzen dute (Keen \& Pease, 2016).

Honen guztiaren aurrean, hemen aurkezten den lana ardazten duten galderak hauexek dira: Errazten al dute Ikaskuntza Zerbitzuan oinarritutako Gradu Amaierako Lanek etorkizuneko Hezkuntza Graduko ikasleen 
identitate hezitzailearen eraikuntza? Horrela balitz, Ikaskuntza Zerbitzuari esker, garatu al dira alderdi profesionalarekin lotzen den jakintza akademikoa zein praktika profesionala? Eta alderdi pertsonalean kokatutako zein jarrera, sinesmen, eta balio sustatu dira? Horiek guztiak argituz gero, Ikaskuntza Zerbitzuan oinarritutako Gradu Amaierako Lanen eskaintza akademikoa egokitu eta hobetu ahalko litzateke etorkizunean.

Ikerketa galdera honi heldu aurretik, Ikaskuntza Zerbitzuaren inguruko bibliografia berrikusiko da lehenik. Ikaskuntza Zerbitzuaren definizio, estrategia metodologiko gisara dituen oinarri pedagogikoak, eta garapen pertsonal zein profesionalerako egiten dituen ekarpenak aurkeztuko dira gero. Azken hauek, Ikaskuntza Zerbitzuak egiten dituen ekarpenak alegia, Hezkuntza eta Kirol Fakultatean eskaintzen diren Gradu Amaierako Lanen xede eta gaitasunekin lotuko dira. Ondoren, aztergai izango diren zerbitzuen hainbat zehaztapen emango dira: Ramón Bajo eskolan kokatu eta garatuko direla argituko da, ikasle bakoitzak egin duen lana deskribatuko da, eta zerbitzuaren diseinu, inplementazio eta ebaluaziorako jarraitutako urratsak zeintzuk izan diren adieraziko da.

\section{IKASKUNTZA ZERBITZUA}

Nazio Batuen Garapen Iraunkorrerako 2030 Agenda mundua eraldatzeko ekintza plana da (Nazio Batuen Batzar Nagusia, 2015). Argi dago xede hau gobernuen esku soilik ezin dela egon, eta zehaztutako helburuak lortzeko instituzio guztien inplikazioa ezinbestekoa dela. Instituzioen artean, azpimarragarria da Unibertsitateak plan horren gauzatzean har dezakeen buruzagitza.

Erronka berri horrek unibertsitateko hezkuntza-praktika egokitzea dakar, eta 2010eko abenduaren 31n, Unibertsitateko Ikaslearen Estatutua onartzen duen 1791/2010 Errege Dekretuan zehaztuta agertzen den moduan, autonomia, erantzukizuna, inklusioa eta justizia sozialaren garapena ahalbideratzea izan beharko luke oinarri. Hainbat adituk Ikaskuntza Zerbitzua, aurreko dena garatzeko irakaskuntza metodo berritzaile egokitzat hartzen dute (Aramburuzabala, Cerrillo \& Tello, 2015).

Euskal Herriko Unibertsitatean (UPV/EHU) bide hau ez da berria. Gezuraga-k, 2014. urtean, Ikaskuntza Zerbitzuan oinarritutako praktikak identifikatu, jaso, ikusgarri bilakatu eta aztertu zituen bere doktore-tesian. Autore horrek UPV/EHUn egin den ibilbidearen berri ematen jarraitzen du baina transferentzian bereziki fokua jarrita (2017).

\subsection{Ikaskuntza Zerbitzua definitzen}

Ikaskuntza Zerbitzua deritzon estrategia metodologikoak zerbitzu komunitarioa curriculumarekin integratzen du, non ezagutza esperientziala, ezagutza 
disziplinarra edo akademikoarekin lotzen den, errealitatearekiko hartu eta gauzatu den konpromisoaren inguruko hausnarketa eginez (McIlrath, et al., 2016).

Definizio horren arabera, antzekotasuna duten hainbat praktika Ikaskuntza Zerbitzutik bereizten dira. Clayss-ek 2016an argitaratutako gidan agertzen den moduan (ikusi 1. irudia), solidarioak diren praktikak bi ardatzen arabera antola daitezke: zerbitzuaren kalitatearen arabera, eta ikaskuntzaren kalitatearen arabera. Bi ardatz horien arabera, beheko koadrantean, aldizkako ekintza solidario asistematikoek ez lukete eskainiko kalitate handirik zerbitzuan, ezta ikaskuntzan ere. Kontrako koadrantean Ikaskuntza Zerbitzua dago, zeinean eskainitako zerbitzua eta garatutako ikaskuntza kalitate handikoak izaten diren. Curriculumarekin loturarik ez duten eta boluntarioak diren lan sistematikoen bidez kalitate handiko zerbitzuak eskaintzen dira, baina ikaskuntza kurrikularrik ez da egoten. Aldiz, helburu solidariorik ez duten kanpo ekintza edo egonaldietan ikaskuntza kurrikularra izaten da xedea, eta ez eman daitekeen zerbitzua.

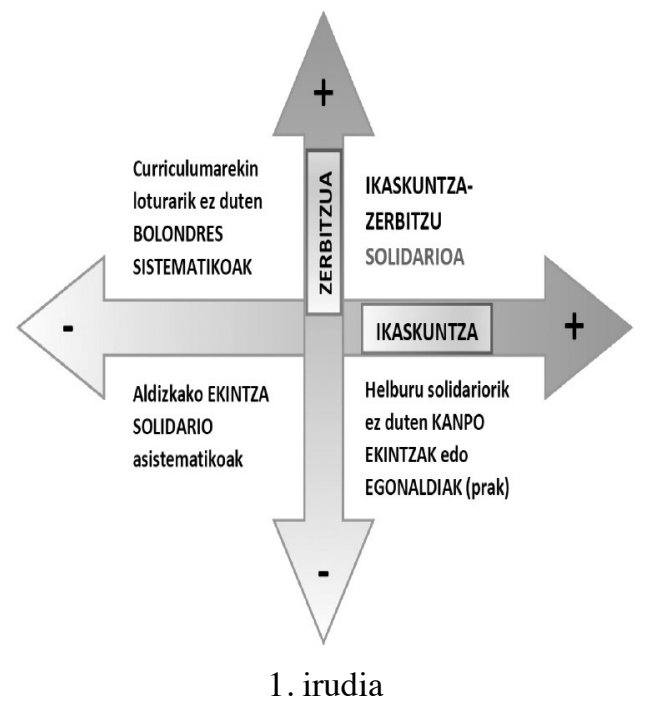

Ikaskuntza Zerbitzua beste praktika batzuekin alderatuta

Iturria: Clayss-ek 2016an argitaratutako gidatik egokitutako irudia

\subsection{Ikaskuntza Zerbitzuaren oinarri pedagogikoak}

Ikaskuntza Zerbitzua zer den eta zer ez den argitu ostean, irakaskuntza metodo horren justifikazio teorikoa egitea garrantzitsua da, xx. mendean, onarpen handia baitu eta gaur egun oraindik erreferente izaten jarraitzen duten pedagogoekin lotuta agertzen baita. 
Hezkuntza-instituzioetan arreta jarriz, Álvarez eta Silio-k (2015) zehazten dute Ikaskuntza Zerbitzua bultzatzen duten horiek industria-eredutik aldentzen diren erakundeak izaten direla. Hori dela eta, Ikaskuntza Zerbitzua ikuspegi pedagogiko berriekin lotzen ez bada ere, berritzailea dela kontsidera daiteke Freire-ren (1971) nahi edo asmo eraldatzailearekin bat egiten duelako, eta sintonian dagoelako Delors (1996) eta Tedesco-k (2000) azpimarratzen duten ezagutza praktiko, garapen pertsonal zein sozialarekin.

Ikas-irakaste prozesuei dagokienez, Furco-k (2001) Ikaskuntza Zerbitzuaren inguruan hitz egiten duenean, adierazten du konstruktibismo soziala oinarrian dagoen ikas-irakaste paradigma dela. Ikuspegi eraikitzailea hainbat aldarrikapen barne hartzen ditu. Testu honetan, Ramírez eta Pizarro-k (2005) jasotakoak gogora ekarriko dira. Konstruktibismoaren oinarrietan badago ziurtasun hau: eskolak ez ezik, gainontzeko testuinguru sozial zein kulturalek ere eragiten dutela norberak eraikitzen duen ezagutzaren garapenean.

Hortaz, ezagutza norberaren ezaugarriek baldintzatuta dagoen eraikuntza bada, ikasleen protagonismoa bermatzea ezinbestekoa litzateke, irakaslea prozesuaren bidaide bilakatuz. Folgueiras eta Martínez-ek 2009. urtean egin zuten azterketari esker, agerian gelditu zen Ikaskuntza Zerbitzuan eraikitzen diren erlazioen gakoa elkarrizketa dela, non irakaslea bera kolokan jarria izan daitekeen eta egiaren jabe izateari uzten dion. Aurreko autoreek irudikatutako ikas-irakaste prozesu horrek Freire-ren (1971) ikaskuntza dialogikoarekin bat egiten du.

Harreman eta elkarrizketaz gain, esperientzia eta aurkikuntza dira giltza. Horrela, ezagutzaren garapen esanguratsua - aurreko jakintza edo ziurtasunak kolokan jarri ostean, horietaz egin den berreraikuntza, osaketa - ahalbideratzen da (Ramírez \& Pizarro, 2005). Esperientziaz hitz egiten dugunean, Dewey eta bere obra, bereziki 1995. urtean argitaratutakoa, diskurtsora ekartzea ezinbestekoa da. Esperientzia bidezko ikaskuntza aldarrikatzearen muinean sinesmen hauxe dago: ezagutzaren garapena gauzatzen da esperientziak dakarren eraldaketari esker. Dewey-ren filosofiak ezagutzaren eta ekintzaren arteko loturan du oinarria, «learning by doing» esamolde famatuaren bidez jasoa izan dena.

Aurrekoak eskatzen du ikas-irakaste prozesua errealitatean kokatua egotea eta errealitate horren erronkei erantzuna ematea, garatutako ezagutzak praktikan jarriz (Ramírez \& Pizarro, 2005). Hortaz, errealitatearekin egon behar den lokarriak eramaten gaitu komunitatearekin, hau da, munduarekin harremanetan egotera, saretuta egotera. Aliantza horiei esker, inplikatuta dauden agenteen edo beren ordezkarien bidez, errealak diren egoerak, arazoak edo erronkak hezkuntza testuingurura eramateko aukera egoten da.

Azkenik, hausnarketari utziko zaio lekua. Hausnarketaz diharduten autore asko daude, baina artikulu honetan hizpide izango dugu Dewey-ren (1995) esperientzia bidezko ikaskuntzarekin oso lotuta dagoen eta Ikaskuntza Zer- 
bitzuan burutu behar diren faseekin (Tapia 2006) - aurrerago azalduko direnak - oso bat datorren Kolb-en (1984) ezagutzaren garapen eredua, «Experiential Learning Model» delakoa, alegia. Autore horren ustez esperientziaren eraldaketak jakintza, hazkuntza, dakar, eta ezinbestekoa da hausnarketa eraldaketa hori gerta dadin. Hori sustatzeko 4 fase aurreikusi zituen:

1. fasean, errealitatearen behaketa da garrantzitsuena («EC»)

2. fasean, hausnartutako behaketan oinarritzen da («OR»)

3. fasean, hausnartutako hori teoria edo paradigma batean kokatzen da $(« \mathrm{CA} »)$

4. fasean, hautatutako teoria edo paradigmaren arabera, ekintzaren bat planifikatzen, inplementatzen eta ebaluatzen da («EA»)

Hausnarketa amaierarako uzteak ez du esan nahi, Ikaskuntza Zerbitzuaren osagaietatik, hausnarketa denik garrantzia gutxien duena. Guztiz kontrakoagatik laga da gai hori puntua ixteko. Aurreko oinarri pedagogiko guztiak azaldu aurretik garatuko balitz, ez luke hainbesteko esanahirik izango.

\subsection{Ikaskuntza Zerbitzuaren ekarpenak}

Adituek Ikaskuntza Zerbitzuak inpaktua duen alderdi anitz identifikatzen dituzte. Ikasleen parte hartzeak duen garrantzia aintzat hartuta, zenbait autorek aldarrikatzen eta frogatu izan dute estrategia metodologia honek eragina duela autonomian, ekintzailetzan, gaitasun kritikoan, hiritartasunean eta horrekin lotutako balioetan oinarritzen den erantzukizun sozialean, hala nola justizia edota inklusioa (Baldwin, Buchanan \& Rudisill, 2007; Bringle \& Hatcher, 2004; Lorenzo \& Matellanes, 2013; Mendia, 2012; Rosenberger, 2000; Saltmarsh, 2005).

Aurretik aipaturiko parte hartzea ez da soilik ikasleetara mugatzen, Ikaskuntza Zerbitzuan hezkuntza-eragile guztiek parte hartzen dute. Horrek baimentzen du elkarrekikotasunean oinarritutako harremanen eraikuntza. Hortaz, Sigmon-ek (1979) zioen moduan, edonork dauka ikasteko zein irakasteko aukera. Erlazio hauek ekartzen dituzten esperientzien ondorioz, autokontzeptu zein autoestimu positiboagoa garatzen da (Billing, 2002). Horrez gain, bakoitzak laguntza edo ekintza sozialetarako izan ahal duen gaitasunaren inguruan aukera aproposak eraikitzen laguntzen dute baita ere (Zhang, et al., 2011).

Azkenik, harremanetan fokua jarrita, jakin badakigu, interakzio osasuntsuak gerta daitezen, gaitasun komunikatiboa dela gakoa, hau da, gainontzekoen pentsamendu zein sinesmenen ulermena. Horren harira, zenbait adituk egiaztatu dute Ikaskuntza Zerbitzuak hobekuntzak ekartzen dituela: gaitasun komunikatiboan (Billing, 2002); eta edonork harreman sozial berrien eraikuntzan irudika dezakeen arrakastan (Lorenzo \& Matellanes, 2013; Maynes, Hatt \& Wideman, 2013). 


\subsection{Ikaskuntza Zerbitzuaren eta Gradu Amaierako Lanen arteko lotura}

Ikaskuntza Zerbitzua bitarteko bideragarritzat jo da Euskal Herriko Unibertsitateko Hezkuntza eta Kirol Fakultatean, Hezitzaileen Formakuntzan eskaintzen diren Gradu Amaierako Lanetan zehaztuta dauden konpetentziak garatzeko.

Gure Fakultatearen Gradu Amaierako Lanen xedea hauxe da: Hezitzaileen Formakuntzako ikasleei interesatzen zaien hezkuntza arlo konkretu batekin lotuta dauden datuak eskuratuko ditu, ondoren horien azterketa hausnartua, kritikoa eta etikoa eginez, proposamen berritzaile edota sortzaileak egin ahal izateko. Azterketaren inguruan adierazten den horretan arreta jarriz, ikus daiteke lotura dagoela Ikaskuntza Zerbitzuaren inguruan esandakoarekin. Diskurtso bietan, hausnarketari, ikuspegi kritikoaren garapenari, zein etikari (justiziari, inklusioari) garrantzia ematen baitzaie.

Gaitasunei dagokionez, lau dira Hezitzaileen Formakuntzako Gradu Amaierako Lanei esker ikasleengan aurreikusten diren konpetentziak. Lehenengo gaitasunak ezagutza teoriko zein praktikoaren arteko loturari egiten dio erreferentzia. Ikaskuntza Zerbitzua definitua izan denean, zehaztu egin da, hausnarketaren oinarria esperientzia bidezko ikaskuntza (ezagutza praktikoa dena) eta ezagutza disziplinarra edo akademikoa (ezagutza teorikoa dena) harremanetan jartzea dela. Bigarren gaitasuna eskolatze-prozesuen azterketa eta hobekuntzan zentratzen da. Ikaskuntza Zerbitzuaren kontzeptua taxutzean adierazi da komunitatearen behar bati erantzuna emateko asmoa duen zerbitzua antolatu behar dela. Hemen, zehaztu behar da komunitatea, eskola bera izan dela, eta justizia edo inklusiorako oztopo diren egoerak identifikatu eta aztertu ostean, zerbitzua antolatu dela errealitate zehatz hori hobetzeko helburuarekin. Hezitzaileen Formakuntzako Gradu Amaierako Lanetan zehazten diren azken bi gaitasunak autonomia eta gaitasun komunikatiboa dira. Aurretik agerian gelditu den moduan, baiezta daiteke Gradu Amaierako Lanen bi gaitasun horiek Ikaskuntza Zerbitzuak ahalbideratzen dituen horien artean daudela.

\section{IKASLEEK ESKAINITAKO ZERBITZUEN ZEHAZTAPENAK}

\subsection{Zerbitzuen kokapena}

Lan honetan, aztergai izan diren zerbitzuak Ramon Bajo eskolan aurrera eraman dira. Hezkuntza zentro hau Vitoria-Gasteizko alde zaharrean kokatuta dago.

1980. urtean sortu zen auzo-eskola moduan, eta gaur egun espiritu berberarekin jarraitzen du (Agirre, 2010). Hala ere, hainbat alderdi galdu ez diren arren, urte hauetan aldaketak gertatu dira. 
1995. urtean, Berritzeguneko aholkularien eskutik Ikas Komunitateei buruzko formakuntza jaso zuten. Horren berri izatean, eskola eredu horrek beren beharrekin bat zetorrela ikusi zuten, ikasleek duten profil multietnikoari egoki erantzun ahal izateko eta profesionalen praktika zein antolakuntza eraldatzeko. Hortaz, ondorengo urteetan, hezkuntza komunitatea eratzen duten eragile guztien parte hartzeari esker, eman beharreko urratsak gauzatu zituzten, 1997. urtean Ikas Komunitate bilakatuz, zeinek helburu nagusi moduan, ikaskuntza sustatzea eta ikasleen arteko ezberdintasuna murriztea izan zuen (Luna \& Jaussi, 1998).

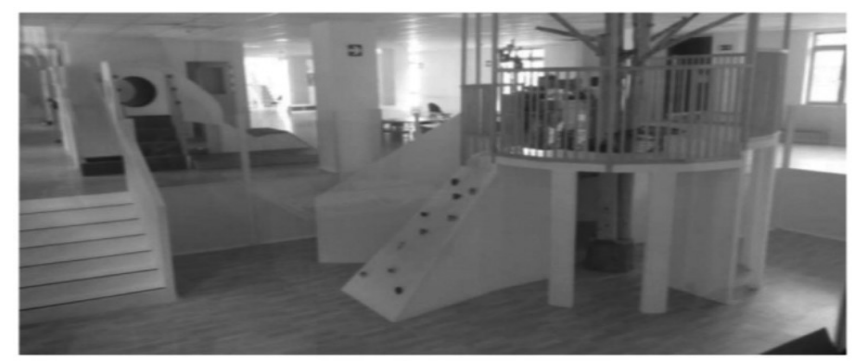

2. irudia

\section{Ramon Bajo eskolako barne espazioa}

Ramon Bajo eskola gizartera begira dagoen «leiho kritikoa» izan beharko litzatekeela iruditzen zaie bertako profesionalei, beti ikuspuntu konstruktibotik etorkizuna sortzeko eta hobetzeko asmoz. Postulatu hau bete dadin, eskolak «familia txiki-handi» bat bezala funtzionatu behar duela pentsatzen dute; senide, ume eta irakasleek elkarrekin bizi direlako errespetuz eta elkar maite dutelako. Baina ez bakarrik hori, auzoko elkarteekin harremanetan egotea beharrezkotzat jotzen dute. Elkarlanean aritzeak baimentzen du komunitatearen garapen integralaren zerbitzura dauden berrikuntza pedagogiko txiki zein handietan murgilduta egotea.

Etengabeko hausnarketa eta hobekuntzarako grina horrek berrikuntza pedagogiko sakon eta luze baten alde egitera eraman zuen eskola 2014. urtetik gaur egunera. Eskolak eraldaketa arkitektoniko zein metodologikoa gauzatzearen ardura hartu du (ikusi 2. irudia), kalitatezko hezkuntza publikoa eskaini ahal izateko (Aguado et al., 2018). 1997. urtean zehaztutako xedeari jarraituz, ikaskuntza bultzatu nahi dute esperimentazioan oinarritutako proposamen ludikoen bidez (Aguado et al., 2018). Prozesu honetan, aditu ezberdinen laguntza jaso dute bertako profesionalek, horien artean Hezkuntza eta Kirol Fakultatearen bi irakasle izan dituzte bidaide, artikulua sinatzen duten bi irakasle, hain zuzen ere. 


\subsection{Zerbitzu bakoitzaren deskripzioa}

Aztertutako Hezitzaileen Formakuntzako Gradu Amaierako Lanen prozesu hauetan bi zerbitzu eskaini izan dira. Alde batetik, bazkalostean, eskolaz kanpoko eskaintzetan matrikulatuta ez dauden Haur Hezkuntzako umeentzat ongizate eta garapenerako testuinguruen sorreran oinarrituta dagoena izan dugu. Bestetik, Ramon Bajo eskolako Haur Hezkuntzako irakasle-taldean, Hezkuntza eta Kirol Fakultateko bi irakaslek eskainitako aholkularitzari esker, garatzen ari den kultura-aldaketa aztertu da.

Bi zerbitzu hauek hobeto irudikatu ahal izateko, jarraian, bakoitzaren inguruko hainbat zertzelada eskainiko dira.

Bazkalosterako, ongizate eta garapenerako testuinguruak umeentzat sortzea

- Abiapuntua: Bazkalosteko tartean desberdintasunak daude umeen artean maila sozioekonomikoarengatik, hau da, ume batzuek Guraso Elkarteak eskaintzen dituen ekintzetan, diruz ordaindu beharrekoak direnetan, parte hartzeko aukera dute, eta beste batzuek, aldiz, ez.

- Helburua: Ikaskuntza Zerbitzuaren esperientziaren bidez, bazkalostean, Guraso Elkarteko eguerdiko ekintzetan parte hartzen ez duten umeen ongizate eta garapena sustatuko duten testuinguruak diseinatu, inplementatu eta ebaluatzea izan dugu xedetzat justizia sozialaren ikuspuntutik.

- Zerbitzua: Eskolaren kanpo espazioan, hots, patioan dagoen baratzean hain zuzen ere, esperimentazioan oinarritutako proposamen ezberdinak eskaini dira.

- Gauzatzea: Gradu Amaierako Lanaren txostena, jardueretarako sortutako materiala eta esperientziaren argazkiak (ikusi 3. irudia).
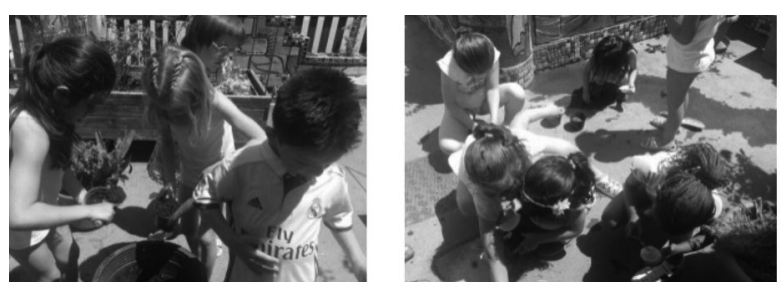

3. irudia

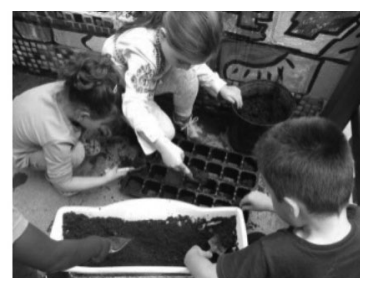

Ramon Bajo eskolako baratzean eskainitako testuinguruen adibideak 
Haur Hezkuntzako irakasle-taldearen kultura-aldaketaren azterketa, aholkularitzari esker

- Abiapuntua: Ramon Bajo eskola berrikuntza pedagogikoan murgilduta egonik, Haur Hezkuntzako irakasleei hainbat kezka, zalantza, sortu zaizkie beren praktikaren inguruan. Momentu horretan, bereziki, argitu nahi dutena zera da: umeen gaitasunak nola behatu eta ebaluatu daitezkeen.

- Helburua: Aholkularitza eskaintzen duten Hezkuntza eta Kirol Fakultateko bi irakasleek proposatutako ibilbidearen eraginkortasuna aztertzea izan dugu helburutzat. Zehazkiago, jakin nahi izan da ea aurrera eraman den prozesuak Haur Hezkuntzako irakasletaldearen kulturaren aldaketa sustatu duen.

- Zerbitzua: Aholkularitza saioen behaketa zein irakasleen prozesuaren jasoketa eta azterketa egin da kultura aldaketa ebidentziatan oinarritu nahian.

- Gauzatzea: Gradu Amaierako Lanaren txostena, saioen behaketarako sortutako erreminta, eta irakasleen prozesuaren hautematea jasotzeko tresnak.

Amaitzeko, zehaztu behar da, zerbitzu bakoitzak, eskolaren beharrei erantzun ahal izateko, 20 ordu baino gehiagoko dedikazioa izan duela ikasle bakoitzarentzat.

\subsection{Zerbitzuak eskaintzeko emandako urratsak}

Esperientzia honetan jarraitu ditugun urratsak, orain dela 18 urte, irakasle zein adituek hasitako hausnarketa partekatuaren ondorioa dira (CLAYSS, 2016). Horietan oinarrituz, zerbitzua prestatzeko, gauzatzeko eta ebaluatzeko 5 urrats nagusi zehazten dira: motibazioa; diagnostikoa; diseinua eta planifikazioa; exekuzioa; eta itxiera. Urrats nagusi horiek zeharkako 3 prozesuekin bat egiten dute: hausnarketa; erregistro, sistematizazio eta komunikazioa; eta ebaluazioa. Tapia-k (2006) fase bakoitzak hartzen dituen ekintzak zehaztu zituen. Horietan oinarrituz, jarraian guk egindako prozesua azalduko dugu (ikusi 4. irudia).

- Motibazioa: Ikasleek ez dakite zer den Ikaskuntza Zerbitzua Gradu Amaierako Lana aukeratzen dutenean. Hortaz, lehenengo erron$\mathrm{ka}$, honen inguruan trebatzea da. Ikaskuntza Zerbitzua zertan datzan azaltzean, identitate hezitzailearen eraikuntza errazten duela argitzen da, ikasleengan motibazioa bermatu edo indartu nahian.

- Diagnostikoa: Pausu honetan bi bilera antolatzen dira. Lehenengoan, Hezkuntza eta Kirol Fakultateko irakasleak Ramon Bajoko eragileekin biltzen dira haiek identifikatuta dituzten erronken berri 
izateko. Horietatik guztietatik, Gradu Amaierako Lanen helburuekin bat datozenak zeintzuk diren identifikatzen dira modu partekatuan. Hau argitzean, ikasleei jakinarazten zaie zeintzuk diren adostutako zerbitzuak. Bigarren bilera antolatzen da ikasle eta Ramon Bajoko eragileen arteko komunikazioa bermatzeko. Horretan, Hezkuntza eta Kirol Fakultateko irakasleak bitartekari moduan aritzen dira, eskolaren interesak zein ikasleen formakuntza zaintzen ahaleginduz. Jasangarritasuna ziurtatzea xedetzat izaten dute irakasleek, hartzen diren konpromisoak egingarriak izan daitezen.

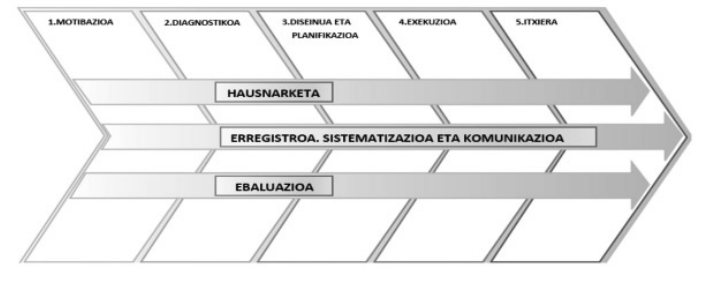

4. irudia

Ikaskuntza Zerbitzuan jarraitutako prozesua

Iturria: Clayss-ek 2013an argitaratutako gidatik hartutako eta egokitutako irudia

- Diseinua eta planifikazioa: Prozesuaren puntu honetan, helburuak, diseinua, eta planifikazioa zehazten dira. Gradu Amaierako Lanen xedeak, Ikaskuntza Zerbitzuaren oinarriak, Ramon Bajo eskolaren beharrak, eta ikasleen interesak aintzat harturik, zerbitzua ardaztuko duten helburu orokor eta espezifikoak adosten dira. Bibliografiaren berrikuspenean oinarrituz, ikasle bakoitzak erabakitzen du zer-nolako zerbitzua garatuko duen helburuei erantzuteko. Diseinuarekin bukatzean, exekuzioaren eta ebaluazioaren planifikazioa egiten da; kronograma batean arduradunak, egitekoak, kokapenak, eta epeak jasoz alde batetik, eta Fakultatean eta Ramon Bajon dauden baliabideak aztertuz, bestetik.

- Exekuzioa: Ikasleek zerbitzuak inplementatzen dituztenean gauzatzen da fase hau. Exekuzioan ezustekoak gertatu ohi direnez, diseinatutakoa eta planifikatutakoa malgutu behar izaten da. Egokitzapen horiek bideratzeko, parte hartzen duten eragile guztien arteko komunikazioa etengabea da (Fakultateko irakasleen eta ikasleen artekoa, ikasleen eta Ramon Bajoko eragileen artekoa, Fakultateko irakasleen eta Ramon Bajoko eragileen artekoa). Gainera, dinamismo horren kontzientzia har dezaten, ikasleek beren egunerokoetan dena erregistratzen dute modu sistematizatuan.

- Itxiera: Ikasleek zerbitzua amaitzean, prozesuaren ebaluazioa egiten dute. Gradu Amaierako Lanaren defentsa burutu ostean, eginda- 
ko bidearen bukaera ospatzen da parte hartu duten eragile guztiekin bilduz. Topaketa horretan, Rafa Mendia-ren ${ }^{1}$ presentzia izan genuen, zeinek Ikaskuntza Zerbitzuaren markoa jarri zuen. Ondoren, Fakultateko irakasleek sarrera txiki bat egin zuten, ikasleei ahotsa emanez, Gradu Amaierako Lanaren aurkezpena egiteko. Ikasleek arreta jarri zuten beren indarguneetan zein proiektuarenetan eta hobetzeko ildoetan hausnarketa kolektiboari sarrera emanez.

\section{IKERKETA LAN HONEN HELBURUA}

Euskal Herriko Unibertsitateko Hezkuntza eta Kirol Fakultatean abian jarritako esperientzia pilotu honetan, Ikaskuntza Zerbitzuan oinarritutako Gradu Amaierako Lanak eskaini izan dira (Cruz, López \& López-de-Arana). Parte hartu dutenen bizipenak aztertuko dira jakiteko zer-nolako efektua duten Ikaskuntza Zerbitzuan oinarritutako Gradu Amaierako Lanek ikasleen identitate hezitzailean, eskaintza akademiko horren indarguneak eta hobetzekoak identifikatu ahal izateko.

Helburu orokor nagusia zehaztuta, helburu espezifikoak zehaztuko dira. Marko teorikoan oinarrituz biren harira antolatuko da ikerketa lana. Alde batetik, Ikaskuntza Zerbitzuan oinarritutako Gradu Amaierako Lanek identitate hezitzailearen alderdi profesionalean duten efektua ezagutu nahi da. Horretarako, arreta jarriko da jakintza akademikoan eta praktika profesionalean. Bestetik, aztertuko da Ikaskuntza Zerbitzuan oinarritutako Gradu Amaierako Lanek identitate hezitzailearen alderdi pertsonalean duten efektua. Kasu honetan, jarrera, sinesmen, edota balioei erreparatuko zaie.

\section{METODOLOGIA}

Jarraian, zehaztutako helburua betetzeko, azterketa kualitatiboaren nondik norakoak azalduko ditugu, lagina, metodoa eta prozedura azalaraziz.

\subsection{Parte hartzaileak}

Azterketa honetan, Hezitzaileen Formakuntzako hiru ikaslek parte hartu dute. Gradu Amaierako Lana gidatu genuen tutoreok bikaina lortu zuten ikasle horiei iradoki genien ikerketa-lan honetan parte hartzeko. Guztira lau ziren,

${ }^{1}$ Rafa Mendia hezkuntzako euskal erreferenteetako bat da. Inklusioa bermatzeko egin $\mathrm{du}$ lan beti, eta hori lortzeko Ikaskuntza Zerbitzua erantzun posible moduan ikusi izan du. Gaur egun, 2006tik jubilatuta egon arren, Ikaskuntza eta Zerbitzu solidarioa xedetzat duen Zerbikas Fundazioarekin kolaboratzen du, bertako presidentea izan ostean. Fundazioaren inguruan gehiago jakiteko ondorengo esteka kontsulta daiteke: http://www.zerbikas.eus 
baina hiruk soilik eman ziguten baiezkoa azkenean. Hirurak emakumeak dira, eta 30 urtetik beherakoak dira. Ikasle bi Haur Hezkuntzako Graduko ikasleak dira, eta bestea Lehen Hezkuntzakoa. Hirurek Hezitzaileen Formakuntzan jarduteaz gain, lanean ere badihardute. Amaitzeko, argitu behar da, «Ikaslea 1» bezala identifikatu dugunak tutore batekin egin zuela prozesua, eta «Ikaslea 2» eta «Ikaslea 3» gisa identifikatutakoek beste tutore batekin.

\subsection{Datuak jasotzea eta analizatzea}

Ikerketa honetan erabilitako metodoa plazaratu baino lehen, zehaztu behar da helburua betetzeko ikasleek prozesuaren amaieran, hau da, Hezitzaileen Formakuntzako Gradu Amaierako Lanaren txostena entregatu eta ahozko defentsa egin ostean, egindako bizitza-historiak aztertu direla. Bizitza-historietan parte hartzaile bakoitzak eraikitzen du bere narrazioa testuinguru konkretu batean izandako esperientzian oinarrituz (Rivas, 2012). Rivas-en (2012) hitzetan, bizitza-historietan, ahots indibidualetan arreta jarri beharrean, eduki sozial, kultural eta politikoan jartzen da.

Hortaz, argi dago azterketa kualitatiboa, eduki-analisiaren (Krippendorff, 1980) bidez egin dela, zeinean Teoria Oinarrituari (Corbin \& Strauss, 2015; Strauss \& Corbin, 1990) jarraituz, kategoriak azaleratuz baitoaz analisia zehar, eta saturaziora heltzean kategoria sistema bukatutzat ematen baitira (Clarke, 2005). Azkenik, aintzat hartu behar da azteketarako analisi unitatea paragrafoak izan direla.

Aurkitu ditugun kategoriak bi dimentsioren arabera antolatu dira. Guztira azalarazitako kategoriak hiru izan dira, baina bi dimentsio izatean, bikoiztuak daude (ikusi 1. taula).

1. taula

\section{Dimentsioak eta kategoriak}

\begin{tabular}{l|l|l}
\hline \multicolumn{1}{c}{$\begin{array}{l}\text { InIMENTSIOAKuneak edo } \\
\text { hobetzekoak }\end{array}$} & $\begin{array}{l}\text { KATEGORIAK } \\
\text { Ikasleen identitate hezitzai- } \\
\text { learen eraikuntzaren balora- } \\
\text { zioa }\end{array}$ & $\begin{array}{l}\text { Alderdi profesionala: jakin- } \\
\text { tza akademikoa eta praktika } \\
\text { profesionala }\end{array}$ \\
\cline { 2 - 3 } & $\begin{array}{l}\text { Alderdi pertsonala: jarrera, } \\
\text { sinesmen, eta balioak }\end{array}$ \\
\cline { 2 - 3 } & $\begin{array}{l}\text { Fakultateko irakasleen prak- } \\
\text { ikantitate hezitzailearen erai- } \\
\text { kuntzaren aldean }\end{array}$ & \\
\cline { 2 - 3 } & $\begin{array}{l}\text { Eskolako eragileen praktika- } \\
\text { ren balorazioa ikasleen identi- } \\
\text { tate hezitzailearen eraikuntza- } \\
\text { ren aldean }\end{array}$ & \\
\hline
\end{tabular}




\subsection{Prozedura}

Ikerketa lan honek fase ezberdinak izan ditu. Lehenengo fasean ikasleek Ikaskuntza Zerbitzuan oinarritutako Gradu Amaierako Lana burutu behar izan dute.

Horren ostean, bigarren faseari ekin genion datu bilketari hasiera emanez. Horretarako, Ikaskuntza Zerbitzuan oinarritutako Gradu Amaierako Lanaren txostena eta ahozko defentsa bukatu ostean, ikasleei eskatu genien prozesuaren inguruan beren bizitza-historia ekoiztea. Beren prozesuaren berri ematea eskatu genien honako instrukzio honen pean : «Izan duzuen esperientzian fokua jarrita jakin nahiko genuke prozesua zelako izan den, hau da, izan dituzuen bizipenak, garatu dituzuen konpetentziak, balioak, eta abar». Ikasleei ez genien inolako gidarik eskaini, ez genien adierazi zein ziren garatu behar zituzten puntuak, aztertu nahi genuelako prozesuaren amaieran zerekin gelditzen ziren, hau da, zer egiten zitzaien esanguratsu.

Gure hirugarren fasean, datu-azterketari ekin genion entregatutako datuak aztertuz. Kategorizazio sistema eraikitzeko, lehenengo, bizitza-historiak aztertu ditugu Hezitzaileen Formakuntzako Gradu Amaierako Lanen tutoreen artean, eta, ostean, ikasle bakoitzarekin partekatu dugu kontrasterako. Rivas-ek (2012) aldarrikatzen duen moduan, ikerketa mota hauek estrategia dialogikoak behar dituzte iruzkinen edo narrazioen interpretazioa modu partekatuan bideratzeko. Hortaz, lan honetan aurkezten diren emaitzak, parte hartzaile eta sinatzaile guztien artean adostu.

Behin dena adostuta, laugarren fasean murgildu ginen, non datuen interpretazioan zein ondorioen idazketan jomuga ipini baikenuen.

\section{IKASLEEN NARRAZIOEN AZTERKETEN EMAITZAK}

Orain Ikaskuntza Zerbitzuan oinarritzen diren Gradu Amaierako Lanak burutu dituzten ikasleen narrazioen kategorizazioaren berri emango dugu. Kategoria bakoitza ikasleen ahotsen bidez eraiki da.

\subsection{Indarguneak}

Ikaskuntza Zerbitzuan oinarritzen diren Gradu Amaierako Lanen indarguneak identifikatzeko, kategoria hauetaz baliatu gara: a) ikasleen identitate hezitzailearen eraikuntzaren balorazioa, b) Fakultateko irakasleen praktikaren balorazioa ikasleen identitate hezitzailearen eraikuntzari dagokionez, eta c) Ramon Bajo eskolako eragileen praktikaren balorazioa ikasleen identitate hezitzailearen eraikuntzari dagokionez. 


\section{a) Ikasleen identitate hezitzailearen eraikuntzaren balorazioa}

Kategoria honetan bi alderdi bereizi dira: alderdi profesionala eta pertsonala.

\section{ALDERDI PROFESIONALA}

Alderdi profesionalari dagokionez, bi gai jorratzen dituzte ikasleek: barneratutako jakintza akademikoa, eta, etorkizunean garatu behar izango duten praktika profesionalarekin lotuta, eskuratutako konpetentziak.

Jakintza akademikoarekin lotuta, ikasle guztiek aitortzen dute «Ikaskuntza Zerbitzua zer zen ez zekitela» (ikaslea1:16-17). Bigarren ikasleak, horrez gain zehazten du «Ikaskuntza Zerbitzuaren eta prosozialitatearen artean dagoen erlazioaz» ohartu dela (ikaslea2:99-100). Hirugarren ikasleak adierazten du «Ikaskuntza Zerbitzuak [...] konpetentzia ugari garatzeko eta barneratzeko aukera» eman diola (ikaslea3:58-59). Gainontzeko ikasleek gehiago argitzen dute zer ikasi duten. Beren narrazioetan agerian gelditzen da zerbitzuaren araberakoa izan dela ikaskuntza. Lehenengo ikasleak onartzen du «haurren gaitasunak behatzeko erabili daitezkeen baliabideak» ezagutu dituela (ikaslea1:4142), «behaketaren bidez, praktikan egin daitezkeen hobekuntzez» konturatu da (ikaslea1:46-47), eta «lanaren inguruan hausnartzeko zein eremu edo egoeretan arreta jarri behar duen» jakin du (ikaslea1:49-50). Bigarren ikasleak azaltzen du «ikerketa txiki bat burutzen» ikasi duela (ikaslea2:97), non «teoria bilatu, aukeratu, idatzi, eta praktikarekin lotu» izan duen (ikaslea2:107-108).

Etorkizunean garatu behar izango duten praktika profesionalarekin lotuta eskuratutako konpetentzien inguruan ere aritu dira ikasleak. Lehenengo ikasleak «etorkizunean burutuko duten lanerako, irakaskuntzarako, alegia, Ikaskuntza Zerbitzua oso baliabide interesgarria dela» dio (ikaslea1:18-19). Hirugarrenak, aurrekoarekin bat eginez aipatzen du Ikaskuntza Zerbitzua «beharrezkoa den metodoa dela, ikastetxe guztietan aurrera eraman beharko litzatekeena» (ikaslea3:18-19). Hori dela eta, «konprometitzen» da «etorkizunean lan egingo dudan ikastetxeetan Ikaskuntza Zerbitzuan oinarritutako proiektuak sustatzera» (ikaslea3:62-63). Ikaskuntza Zerbitzua praktika profesional posible moduan hartu beharrean, estrategia-metodologia horrek berari eskaini dizkion aukeretan fokua jartzen du, hauxe esanez: burututako prozesuan «etorkizuneko irakaslearen lanbiderako ezagupen asko eskuratu» dituela (ikaslea3:61-62). Azkenik, bigarren ikasleak etorkizuneko praktika profesionalerako zer eskuratu duen zehazten du «tailer bat aurrera nola eraman» daitekeen ikasi duela aitortuz; eta «umeengan jartzen duen begirada nolakoa den ikertu» du (ikaslea2:110).

\section{ALDERDI PERTSONALA}

Alderdi pertsonalari dagokionez, hirugarren ikasleak hauxe adierazten du: «Ikaskuntza Zerbitzuak [...] konpetentzia ugari garatzeko eta bar- 
neratzeko aukera eman» diola (ikaslea3:60-61). Esaldi honetan zehaztasun gehiegi agertu ez arren, narrazioak osotasunean aztertuta 3 gai nagusitu dira: lankidetza, arrakasta, eta erantzukizuna.

Bigarren ikaslea izan da lankidetzaz gehien hitz egin duena. Esperientziaren hasieran, ikasle horrek «frustrazioari aurre egin behar izan» zion (ikaslea2:103-104). Alde batetik, «buruan zeukan zerbitzua, eskolaren beharretara egokitzen ez zenez, egoera onartu behar izan zuen bide berriak berreraikiz» (ikaslea2:104-105). Bestetik, «bere moduan pentsatzen ez zuten kideekin (eskolakoak zein ikaskideak) batera proiektu berri bat» sortu behar izan zuen (ikaslea2:105-106). Horregatik guztiagatik, «maila pertsonalari dagokionez prozesua frustragarria izan dela» (ikaslea2:47), «gauzak, askotan, ez direlako ateratzen guk espero dugun moduan» (ikaslea2:4950). Bizipen horren ondorioz, aitortzen du «ikasketa oso garrantzitsua atera duela: pertsona bakoitza mundu bat izanik, ahal den neurrian mundu horien arteko elkar ulermena bermatzen saiatu behar dela, eta horretarako bestearen iritzia onartzea, eta askotan amore ematea» (ikaslea2:61-64) beharrezkoa dela. Gehien garatu dituen gaitasun pertsonalak «lasaitasuna, tolerantzia, eta pazientzia» (ikaslea2:88-89) direla dio.

Arrakasta sentsazioari dagokionez, ikasle guztiek diote prozesu eta emaitzekin pozik daudela: «entretenigarria» (ikaslea1:38) iruditu zaio lehenengoari, eta bigarrena «kontent» gelditu da (ikaslea2:48). Pozik egotearen arrazoia maila pertsonalean «lortutako ezagutza handiak» (ikaslea2:49) dira bigarren ikaslearen hitzetan. Lehenengo eta hirugarren ikasleak aldarrikatzen dute burututako Gradu Amaierako Lanaren funtzionalitatea, hau da, «zerbaitetarako balio izan duela» (ikaslea1:53). Lehenengo ikasleari, etorkizuneko «lanaren inguruan hausnartzeko» baliagarria izan zaio (ikaslea1:49). Eta hirugarren ikasleak Ikaskuntza Zerbitzuaren bidez «etorkizuneko irakaslearen lanbiderako, balio zein konpetentzia ugari garatzeko eta barneratzeko aukera» izan duela pentsatzen du (ikaslea3:60-62).

Hirugarren ikasleen narrazioan erantzukizuna agertzen da. Eskolarekin adostu bezala, ortuan tailerrak eskaini zituzten; hala ere, «zerbitzuarekin bukatzerakoan bazkalosteko denbora hori bete gabe gelditu zen» (ikaslea3:47-48), hau da, baliabide ekonomikorik ez duten familien umeak doako jarduera barik gelditzen dira berriro. Horren aurrean, zerbitzua eraldatzaileagoa bilakatu nahian ondorengoa proposatzen du: «jantokiko monitoreentzako formazioa prestatzea haiek tailerrak aurrera eraman ditzaten» (ikaslea3:48-50).

\section{b) Fakultateko irakasleen praktikaren balorazioa ikasleen identitate hezitzailearen eraikuntzari dagokionez.}

Irakasleen inguruan hitz egitean, ikasleek gehien errepikatzen duten hitza «laguntza» da. Lehenengo eta bigarren ikasleek laguntza kokatzen dute «marko teorikoaren» eraikuntzan (ikaslea1:27-28; ikaslea2:95). Horrez gain, lehenengoak ere jasotzen du «zerbitzuaren» exekuzioan klabea izan dela ira- 
kaslea (ikaslea1:28-29). Laguntza horrek ekarri du gero eta «lasaiago» eta «gusturago» egon izana (ikaslea1:29). Ikasleei autonomia eskaintzea bigarren ikasleak baloratu du. Bere hitztean «ikasle bakoitzari bere pausuen martxa zein izan behar zen erabakitzeko aukera izan dute» (ikaslea2:73-74). Bigarren ikaslea bezala (ikaslea2:16,22-23), lehenengoak baita ere baloratzen du irakasleek eskolako «errealitatean murgilduta» egoteko aukera eskaini izana (ikaslea1:39). Horri esker, esperientzia «entretenigarriagoa eta benetan zerbaitetarako balio izan duela» pentsatzen du (ikaslea1:38).

\section{c) Eskolako eragileen praktikaren balorazioa ikasleen identitate hezitzailearen eraikuntzari dagokionez}

Ikasleek eskolako eragileen inguruan izan duten harremana aztertzean erakutsi duten irekitasuna goraipatzen dute. Adibidez, bigarren ikasleak hauxe esaten du: «hasieratik ikastetxearekin biltzeko aukera izan dugu» (ikaslea2:29-30). Irekitasunaz gain, bileretan «oso gustura egon» direla aipatzen du lehenengo ikasleak (ikaslea1:39-40).

\subsection{Hobetzekoak}

Ikaskuntza Zerbitzuan oinarritzen diren Gradu Amaierako Lanen hobetzekoak identifikatzeko, honako kategoria hauetaz baliatu gara: a) ikasleen identitate hezitzailearen eraikuntzaren balorazioa, b) Fakultateko irakaslearen praktikaren balorazioa ikasleen identitate hezitzailearen eraikuntzari dagokionez, eta c) Ramon Bajo eskolako eragileen praktikaren balorazioa ikasleen identitate hezitzailearen eraikuntzarekiko eraikuntzari dagokionez.

\section{a) Ikasleen identitate hezitzailearen eraikuntzaren balorazioa}

Indarguneen dimentsioan, kategoria honetan bi alderdi bereizi diren arren. Hobetzekoetan, ikasleek soilik alderdi profesionalari egin diote erreferentzia. Horrekin lotuta, bigarren ikasleak aipatzen du zerbitzua gauzatzen zuen bitartean «ez zuela sentitu umeekin erlazio estua garatzea lortu zuenik» (ikaslea2:82). Honen zergatia- «denbora faltari» edo «estresari» egozten dio (ikaslea2:82-83).

\section{b) Fakultateko irakasleen praktikaren balorazioa ikasleen identitate hezitzailearen eraikuntzari dagokionez.}

Kategoria honen barruan, bi gai nagusi agertu dira: ikasleen egoera anitzak eta esperientziaren diseinu eta planifikazioa.

Ikasleen egoera anitzen inguruan, hirugarrenak egiten ditu ekarpenak. Eramus+ beka bat lortu zuenez, Practicuma bueltan egin behar izan zuen 
maiatzera arte. Horrek ekarri zuen Ikaskuntza Zerbitzuan oinarritutako Gradu Amaierako Lanaren atzerapena. Hori dela eta, proposamen bi egiten ditu: «1) Eramus+ beka ez duten ikasleei eskaintzea bide hau; eta 2) praktika aldia Ramon Bajo eskolan egingo duten ikasleentzat zuzendua egotea, edo Gradu Amaierako Lan hau aukeratzen dutenei praktika aldia Ramon Bajon esleitzea» (ikaslea3:34-35,39-41).

Esperientziaren diseinu eta planifikazioari erreparatuz beste azpi-gai batzuk agertzen zaizkigu: tenporalizazioa, Ramon Bajo eskolarekin izandako harremana, eta adituekin izandako topaketa. Bigarren zein hirugarren ikasleek prozesua gauzatzeko «denbora falta» izan dutela adierazten dute (ikaslea2:102-103; ikaslea3:29). Horrez gain, bigarrenak baita ere harremanetan arreta jartzen du hauxe aipatuz: «ikastetxearekin izandako harremana eskas geratu da» (ikaslea2:73). Hirugarrenak, Rafa Mendiarekin izandako hartu-emana iritzia ematean ondorioztatzen du, «informazioak duen baliagarritasuna kontutan izanik, beharbada aprobetxagarriagoa izango litzateke hasieran kokatzea topaketa» (ikaslea3:53-56).

\section{c) Eskolako eragileen praktikaren balorazioa ikasleen identitate hezitzailearen eraikuntzari dagokionez}

Eskolako eragileekin eraiki den harremanari erreparatuz, ikasleek bi hobetzeko identifikatu dituzte. Alde batetik, bigarren ikasleak pentsatzen $\mathrm{du}$ «euren proposamenei tarte handiagoa utzi beharko lieketela» (ikaslea2:71-72). Bestetik, hirugarren ikasleak ospakizun egunean gertatutako zerbait jasotzen du. Egun horretan, ikasleek egin zuten aurkezpenaren ostean, hausnarketa kolektiboari hasiera eman zitzaion, eta momentu horretan «irakasle batzuk eskatu zuten horrelako ekintzat aurrera eramaten direnean, haiei baita ere helaraztea, euren ardurapean dauden ume batzuk zerbitzuan parte hartu izan zutelako eta eurak ez zekitelako ezer» (ikaslea3:57-58).

\section{ONDORIOAK}

Artikuluari itxiera emateko, ikasleen bizitza-historietatik Ikaskuntza Zerbitzuan oinarritutako Gradu Amaierako Lanen inguruan eratorritako ondorioak plazaratuko ditugu. Bi azpipuntutan antolatu ditugu: ikaskuntza-irakaskuntza prozesu berritzailearen indarguneak (+) eta ikaskuntza-irakaskuntza prozesu berritzailearen hobetzekoak (-).

\subsection{Indarguneak}

Detektatu diren indarguneak jarraian argitzen joango dira, teoriarekin lotuz duten garrantzia justifikatzeko asmoz. 


\section{(+) Jakintza akademikoak eta praktika profesionala garatu dira}

Ikasle guztiek adierazi dute prozesuari esker Ikaskuntza Zerbitzua zer den deskubritu dutela. Horrez gain, ikasle bakoitzak burutu duen zerbitzuaren arabera, ikaskuntza batzuk ere zehazten ditu. Adibidez, lehenengo ikasleak aitortzen du aukera izan duela ebaluazioaz, behaketaz, hausnarketaz, eta irakasle funtzioaz ikasteko. Bigarren ikasleak argitzen du ikasi duela zelan gauzatu ahal diren tailerrak Haur Hezkuntzako umeekin, eta horrez gain, aurrera eramaten duen praktikaren inguruan zelan ikertu ahal den. Azkenik, hirugarren ikasleak ez du gehiegi zehazten, baina onartzen du esperientzia baliagarria egin zaiola etorkizunean izango duen irakasle lanbiderako.

Narrazio hauek bat datoz Clayton, Bringle eta Hatcher (2013) autoreek egiten dituzten baieztapenekin. Egile hauek aldarrikatzen dute Ikaskuntza Zerbitzua irakaskuntza metodo eraginkorra dela giza garapenarekin lotuta dauden hainbat alderdiren garapenerako, baina ez duela alde batera uzten lorpen akademikoa, eta kasu honetan, ikasle batzuek adierazten duten moduan, profesionala baita ere.

Garapen akademiko edo profesionalari itxiera emateko, ikasle guztiek partekatu ez arren, interesgarria da jasotzea ikasle batek azpimarratzen dituen esperientziaren onura bi. Alde batetik, hirugarren ikasleak adierazten du Ikaskuntza Zerbitzua irakaskuntza metodo gisara, lagungarria iruditzen zaiola etorkizunean bere irakasle lanetan inplementatzeko. Honen arabera, ematen du Ikaskuntza Zerbitzuarekin eremu sozial, pertsonal zein akademikoan eragiteaz gain, eremu profesionalarekin ere harremanetan ipin daitekeela. Gainera, azken lotura hau ez da edonolakoa; pentsa daiteke profesionalizazio etikorantz bidea egiten hasteko aukera eskaintzen duela. Bestetik, bigarren onura Ikaskuntza Zerbitzuaren estrategia metodologiarekin lotura zuzena ez izan arren, esperientziaren gauzatzean, ikasleei eskaini zaizkien baliabideekin harremantzen harremanetan jartzen da. Hirugarren ikasle horrek, bere bizitza-historian aipatzen du egunerokoa hausnarketarako tresna eraginkorra iruditu zaiola. Narrazio hau, hausnarketaren sustapenarekin lotuta egon diren eztabaidetan gehitu beharreko ekarpena da. Bakarra denez, aurrerago ildo honen inguruan gehiago ikertzea komenigarria izan daiteke.

\section{(+) Elkarrekin gehiago ikasten da}

Puig-ek eta beste batzuek (2010), Ikaskuntza Zerbitzuaren inguruko garrantzia aldarrikatzean, zehazten dute estrategia metodologiko horrek ez duela bilatzen arrakasta pertsonala. Gero eta agerikoagoa da lehia mekanismo sozial gisara erabiltzeak egonezina ekartzen duela, aldiz, altruismoan oinarritutako jarrerak sustatzeak ongizatea dakarrela. Jokabide altruista horien artean, Puig-ek eta bere lagunek (2010) lankidetza identifikatzen dute. 
Lan honetan jasotako narrazioetan agerian gelditzen da Ikaskuntza Zerbitzuak lankidetzarako aukera ematen duela. Parte hartu duten ikasleek onartzen dute elkarlanak aukera eman diela eskaini behar zuten zerbitzua hobetzeko, egokitzeko, eta koherentzia irabazteko. Puig-ek eta bestek (2010) baieztatzen dute kooperazioa talde lanean aritzen ikasteko giltzarria dela.

Amaitzeko, argitu behar da Puig eta bere taldea ez dela bakarra izan Ikaskuntza Zerbitzua eta lankidetza lotzen. Beste batzuek ere harreman horren berri eman dute, hitz ezberdinak erabili arren. Adibidez, Mendia-k (2012) lankidetzaz aritu beharrean, giza konpetentziari erreferentzia egiten dio, eta Lorenzo eta Matellanes-ek (2013) konpetentzia prosozialei. Clayton, Bringle eta Hatcher (2013), konpetentziez jardun beharrean, erantzukizun sozialaz solasten dira.

\section{(+) Arrakasta-sentsazioa bizi izan da}

Lehen esan bezala, altruismoan oinarritutako jarrerak sustatzeak ongizatea dakar. Puig-ek eta beste kideek (2010) dioten moduan, ematen du eboluzioak sari-sistema neurologikoa ekarri digula gizakioi, aktibatzen dena biziraupena ziurtatzen duten jokabideak izatean. Sari-sistemak dakarren ongizatea islatzen da emozio positiboetan, autoestimuan, egiten denaren zentzuaren topaketan, harrotasunean, bizitza proiektuaren eraikuntzan.

Ikasleen narrazioetan ikus daiteke Ikaskuntza Zerbitzuaren bidez beren sari-sistema aktibatu egin dela, bizi izandakoa egokitzat jo dutelako. Hala ere, horren zergatia ez diete egozten jokabide altruistei. Bakoitzak atribuzio espezifikoa egiten du sentsazio horren inguruan.

Lehenengo eta hirugarren ikasleen ongizatea ikaskuntza prozesuarekin dago lotuta. Bigarren eta hirugarren ikasleen asebetetzea, aldiz, garapen pertsonalarekin lotzen da.

Lehengo zein hirugarren ikasleen narrazioan agerian gelditzen da lanaren funtzionalitateak sentimendu onuragarriak ekarri dizkiela. Ikaskuntza Zerbitzua eta esperientziaren funtzionalitatea edo erabilgarritasuna zuzenean ez dira hain argi lotu literaturan, baina bai lotu izan dela ikaskuntza esanguratsuarekin (Espinosa \& Rodríguez, 2015). Ikaskuntza Zerbitzuak hezkuntza-paradigma tradizionalarekin zeharo apurtzen du, non irakaslea errealitatetik aldenduta egoteaz gain, hezkuntza prozesuaren protagonista bilakatzen den. Ikaskuntza Zerbitzuaren abiapuntua komunitatearen behar bat da, eta horri erantzuteko arduradunak ikasleak dira, zeintzuek garatu beharko dituzten hainbat konpetentzia munduaren ulermena ahalbideratzen dutenak. Hortaz, oinarri horiek ekartzen dute abiarazten den ikaskuntza prozesua zentzuduna, baliagarria eta funtzionala izatea. Hain zuzen ere, azken hausnarketa horretan oinarritzen da lehenengo eta hirugarren ikasleen arrakasta sentsazioa, beraiek esaten duten moduan, Ikaskuntza Zerbitzuaren esperientzia honek aukera eman die gai direla atzemateko eta barneratzeko ezagutzen ez zituzten hainbat konpetentzia. 
Azken bi ikasleek asebetetzeaz hitz egiten dute. Honen zergatia ez da ikaskuntza edo profesionalizazioa, aurreko kasuan ikusi den moduan. Ikasle bi hauen ongizatearen iturriak pertsonalagoak dira. Clayton, Bringle eta Hatcher-ek (2013) garapen pertsonala edo bizitzarako baliagarriak diren trebetasunak aitortzen dizkiote Ikaskuntza Zerbitzuari. Hortaz, ikasle hauek aitortzen duten asebetetzeak lotura izan dezake adituek aipatutako trebetasun horiekin. Ikasleek zehazten dute Ikaskuntza Zerbitzuaren esperientziari esker ikusi dutela gai beren burua frustrazioa kudeatzen eta ziurgabetasunari aurre egiten. Puig-ek eta bere lankideek (2010) dioten moduan, Ikaskuntza Zerbitzuak aukera ematen du hainbat balio edo jarrera garatzeko. Hauen ikaskuntza ezin da teorikoa izan; praktikan eta praktikaren hausnarketaren bidez barneratzen eta garatzen dira. Hezitzaileen Formakuntzako Gradu Amaierako Lan modalitate honek hazkuntzarako aukera eskaintzean asebetetzea dakar.

Emaitza hauek bat datoz Folgueiras, Luna eta Puig-ek (2010) egindako ikerketarekin. Beren lanean aztertu egin zuten Ikaskuntza Zerbitzuan parte hartu zuten ikasleen asebetetze maila. Aurkitu zuten gehiengo batek oso maila altua erakutsi zuela, eta satisfazio horren zergatia esperientziaren baliagarritasuna zela, bai garatutako ikaskuntzagatik, bai maila pertsonalean izandako hazkuntzagatik.

Azkenik, baliagarritasunaren oinarria edozein izanik, pentsatzen dugu horrelako esperientziek ikasleen autokontzeptu positiboago baten garapenean eragin dezaketela, autoestimua elikatzen baita.

\section{(+) Erantzukizun soziala garatu da}

Emaitzetan agerian gelditu den bezala, hirugarren ikasleen narrazioan erantzukizuna agertu da. Ikasle horrek azpimarratzen du zerbitzuari bukaera ematean, hasierako egoerara bueltatzen direla umeak, hau da, baliabide ekonomikorik ez duten familien umeak bazkalosteko tartean eskaintza barik gelditzen direla berriro. Horren aurrean, zerbitzuak injustizia horri erantzuna emateko proposamen bat luzatzen du. Ekarpen hau Ikaskuntza Zerbitzuak sustatzen dituen konpetentzia zibiko eta etikoekin (Clayton, Bringle \& Hatcher, 2013; Lorenzo \& Matellanes, 2013) lotu daiteke. Hala ere, ikasle bakar batek horren berri eman duenez, konpetentzia hauek indartu beharko liratekeela uste izatekoa da. Horretarako, hainbat esku-hartze posible aurreikusten dira: alde batetik, Ikaskuntza Zerbitzuaren helburuak zehazterakoan, konpetentzia horiekin lotutako helburuak zehaztea komeniko litzateke; bestetik, egunerokoa idazteko jarraibideak eman daitezke; eta azkenik, prozesuaren azterketa bizitza-historietara mugatu beharrean, ebidentzia gehiago jasotzea; azkenik, ikasleak aipatzen duen ekarpena azter daiteke, jantokiko begiraleentzat formakuntza prestatzea haiek tailerrak aurrera emateko. Zerbitzua norabide berri horretan abiarazteko, Ramon Bajo eskolak onartzeaz gain, begiraleek ere onartu beharko lukete. 


\subsection{Hobetzekoak}

Indarguneak ez ezik, hobetzekoak ere agerian gelditu dira. Hobetzekoen inguruan argitu behar da parte hartu duten ikasleetatik soilik bik aipatu dituztela, hobetzeko kontuak; bigarren eta hirugarren ikasleek, hain zuzen. Ikasle bi hauek tutore bera izan dute, lehenengo ikasle horretatik bereiziz. Beraz, hobetzeko horiek ikasleen egoerarekin edota tutore horrek bideratutako prozesuarekin lotuta egon daitezkeela uste izatekoa da. Agerian gelditu diren hobetzekoak hiru multzotan antolatu dira.

\section{(-) Praktika profesionala gehiago zaindu behar da}

Lortutako emaitzek alderdi profesionala hobetu beharrari egin diote erreferentzia. Bigarren ikasleak aipatzen du zerbitzua gauzatzen zuen bitartean umeekin eraiki behar den erlazioa ez dela behar bezala zaindu. Zerbitzuaren hartzeaileen kosifikatzeko arriskuaz Aranguren-ek (2018) hitz egiten du. Autore honek salatzen du esperientzia batzuetan komunitatea ikaskuntzaren zerbitzura jartzen dela, eta ez ikaskuntza komunitatearen zerbitzura; zerbitzuaren hartzaileak instrumentalizatuz edo erabiliz euren beharretatik etekina ateraz. Burutzen ari den Ikaskuntza Zerbitzua begirada honen arabera aztertu beharko litzateke, beharrezkoak diren egokitzapenak gauzatzeko.

\section{(-) Ikasleen egoera anitzei erreparatu behar zaie}

Hezitzaileen Formakuntzako Gradu Amaierako Lanak Ikaskuntza Zerbitzuaren bidez gauzatzearen lehenengo esperientzia honetan, ikasleek izan ditzaketen egoeren aniztasuna ez da aintzat hartu. Hori dela eta, hirugarren ikasleak hobetzeko hauek proposatzen ditu: Erasmuseko ikasleei ez eskaintzea horrelako proposamenak, eta ibilbidea errazte aldera, Practicuma eta Gradu Amaierako Lanean eskaini behar den zerbitzua eskola berean izatea.

\section{(-) Esperientziaren diseinu eta planifikazioa egokitu behar da}

Fakultateko irakasleek eskaini izan duten laguntza onartu duten arren, ikasleek diseinu eta planifikazioa egokitzeko beharra azaldu dute. Bigarren zein hirugarren ikasleek tenporalizazioaz hitz egiten dute. Beren tutoreak ikas-irakaste prozesua bideratzeko planifikatutako sekuentzia berrikusi beharko luke, eta hainbat momentu eskolakoekin berriro negoziatu, aurreratze aldera. Horrela, prozesuan galduta egotearen sentsazioa, eta amaieran bizi izan duten larritasun eta lan pilatze hori leunduko litzateke.

Exekuzio fasearen inguruan, bigarren ikaslearen narrazioan agerian gelditzen da eskolako eragileekin izandako komunikazioa ez zaiola beti 
erraza suertatu. Horren ondorioz, aipatzen du «harremana eskas geratu dela». Ikasle baten narrazioa izan arren, kontutan hartzea komeni da. Hortaz, horrelako sentsazioak ekiditeko, Fakultateko irakasleek exekuzio fase horren jarraipen estuagoa egitea interesgarria izan daiteke. Horrela, lagundu ahal diegu ikasleei hobeto kokatzen eskolako beharretan.

Azkenik, Rafa Mendia-rekin izandako hartu-emanaz jardutean ikasle batek ondorioztatzen du, berak eskainitako markoa prozesuaren hasieran gehiago aprobetxatu ahalko luketela, marko teorikoaren eraikuntza eta zerbitzuaren diseinuak daudenean, adibidez. Ekarpen hau aztertzea komeniko litzateke. Horrek ospakizuna birpentsatzea ere ekarriko du.

\section{(-) Eskolako eragileei orientabideak eskaini behar zaizkie}

Eskolako eragileek erakutsi duten irekitasuna goraipatzen dute ikasleek. Baina harreman horietan agertu diren oztopoak gainditzeko, ikasle batek aipatu du beharbada komenigarria litzatekeela ikasleek beraiek eraikitzen dituzten proposamenei espazio gehiago uztea. Ikasle horrek lantzen zituen ekintzak aurkeztean beti egokitu behar izan ditu, eta frustrazio handiz bizi izan du hartu-emana. Hori ekiditeko, Fakultateko irakasleak bitartekari moduan aritzea komeniko litzateke.

Bukatzeko, Ikaskuntza Zerbitzuaren irakaskuntza metodoa inplementatzerakoan Gradu Amaierako Lanetan Ramon Bajo eskolako hainbat eragilerekin aldez aurretik harremana ezarri zen. Adostu zenean elkarrekin egiteko ekimena izango zela, Hezkuntza eta Kirol Fakultateko irakasleak, ikas-irakaste prozesua antolatzeaz arduratu ziren, eta eskolako eragileek bertako profesionalez. Prozesuaren amaieran, ospakizunean azaldu zuten horrelako ekintzen berri eduki beharko luketela, eta hirugarren ikasleak hori jasotzen du hobetzekoen artean. Hortaz, etorkizunean egingo diren ekimenetan garrantzitsua litzateke alderdi hau zaintzea, gogoraraziz eskolako eragileei horren beharra, edo Fakultateko irakasleek horren ardura hartuz.

\subsection{Borobilduz}

Amaitzeko, baiezta daiteke Ikaskuntza Zerbitzuan oinarritutako Gradu Amaierako Lanek errazten dutela Hezkuntza Graduetako ikasleen identitate hezitzailearen eraikuntza. Zehazkiago, lotutako datuen arabera, alderdi profesionalari dagokionez, jakintza akademikoa garatutako zerbitzuarekin dago lotuta (ebaluazioa edo prosozialitatea). Praktika profesionalarekin lotuta, bereziki estrategia metodologikoetan jarri dute arreta, ikasleek berek erabilitakoetan (tailerrak) eta bizi izandakoetan (Ikaskuntza Zerbitzua). Bukatzeko, interesgarria da hausnarketak duen garrantzia aldarrikatzen hasten direla, eta egunerokotasunaren baliagarritasunaz ohartzen direla. 
Alderdi pertsonalari dagokionez, lankidetza, autoestimua, eta erantzukizunaren agerpena azpimarratu daiteke.

\section{ESKERRAK}

Eskerrak eman nahi dizkiogu EHUko Gizarte Erantzukizunaren arloko errektoreordetzari 2016-2017. ikasturtean Iraunkortasunaren arloko Berrikuntzarako laguntzan parte hartzeko aukera emateagatik, eta Berrikuntza, Gizarte Konpromisoaren eta Kulturgintzaren arloko errektoreordetzari 2018-2019. ikasturtean Campus Bizia Lab Proiektuan egoteko aukera eskaintzeagatik.

\section{ERREFERENTZIAK}

Agirre, A. (2010). Colegio público Gasteiz, por una escuela inclusiva y de barrio. Mugak, 50, 22-23. Hemendik hartua: http://mugak.eu/revista-mugak/no-50/ colegio-publico-gasteiz-por-una-escuela-inclusiva-y-de-barrio

Aguado, G., Patarroyo, L. E., Larrañaga, M., Palacín, I., Quilaqueo, V., Mujica, R. M., Modonato, L. \& Ventura, D. (2018). Zaintzen Pedagogia. Eraikitzeko ekarpenak. Bilbo: InteRed Fundazioa. Hemendik hartua: https://intered.org/ pedagogiadeloscuidados/wp-content/uploads/2018/07/Zaintzen-PedagogiaEraikitzeko-ekarpenak-laburpena.pdf

Álvarez, C. \& Silio, G. (2015). El aprendizaje-servicio y las comunidades de aprendizaje: dos proyectos escolares innovadores que se enriquecen mutuamente. Enseñanza \& Teaching, 33(2), 43-58.

Aranguren, J. (2018). Persona y pobreza. Reflexión sobre un posible problema ético de la metodología de aprendizaje servicio. RIDAS, Revista Iberoamericana de Aprendizaje Servicio, 5, 110-122.

Aramburuzabala, P., Cerrillo, R. \& Tello, I. (2015). Aprendizaje-servicio: una propuesta metodológica para la introducción de la sostenibilidad curricular en la Universidad. Profesorado. Revista de Currículum y Formación de Profesorado, 19, 78-95. Hemendik hartua: https://www.ugr.es/ recfpro/rev191ART5.pdf

Ávalos, B. (2002). Profesores para Chile. Historia de un Proyecto. Santiago de Chile: Ministerio de educación.

Baldwin, S. C., Buchanan, A. M. \& Rudisill, M. E. (2007). What teacher candidates learned about diversity, social justice, and themselves from service-learning experiences. Journal of Teacher Education, 58(4), 315-327.

Billig, S. H. (2002). Support for K-12 service learning practice: A brief review of the research. Educational Horizons, 80, 184-189.

Bringle, R. G. \& Hatcher, J. A. (2004). Advancing civic engagement through service learning. Hemen: M. Langseth \& W. M. Plater (Ed), Public work and the academy: An academic administrator's guide to civic engagement and service-learning (125-145). Bolton, MA: Anker Press.

Canton, I. \& Tardif, M. (2018). Identidad profesional docente. Madrid: Narcea. 
CLAYSS (2013). Manual para docentes y estudiantes solidarios (3. ${ }^{\mathrm{a}}$ ed). Buenos Aires: Natura-CLAYSS. Hemendik hartua: http://www.clayss.org.ar/04_publicaciones/Natura2013.pdf

CLAYSS (2016). Cómo desarrollar proyectos de aprendizaje y servicios solidario en la Educación Media (Secundaria y Enseñanza Técnica). Buenos Aires (Montevideo): Ediciones CLAYSS.

Clarke, A. E. (2005). Situational Analysis: Grounded Theory after the Postmodern Turn. Thousand Oaks, California: Sage. Hemendik hartua: http://www.clayss. org.ar/uruguay/2_Secundario.pdf

Corbin, J. \& Strauss, A. L. (2015). Basics of qualitative research: techniques and procedures for developing grounded theory. London: Sage.

Cruz, E., López, A.L \& López-de-Arana, E. (2016). Comienzo de una experiencia de aprendizaje-servicio universitario a través de los trabajos de fin de grado (TFG) de Educación Infantil en la Facultad de Educación y Deporte de Vitoria-Gasteiz de la Universidad del País Vasco (UPV/EHU). Hemen: M. A. Santos, A. Sotelino \& M. Lorenzo (ed.), Aprendizaje-Servicio e innovación en la universidad (199-208). Santiago de Compostela: Servizo de Publicacións e Intercambio Científico.

Delors, J. (1996). La educación encierra un tesoro. Madrid: Santillana-UNESCO.

Dewey, J. (1995). Democracia y educación. Madrid: Morata.

Espinosa, F. \& Rodríguez, V. (2015). Aprendizaje Servicio, una estrategia de aprendizaje significativo en la formación de estudiantes de Terapia Ocupacional de la Universidad Central de Chile. Revista Chilena de Terapia Ocupacional, 1(15), 11-18. Hemendik hartua: https://revistaterapiaocupacional.uchile. cl/index.php/RTO/article/view/37126/38702

Folgueiras, P. \& Martínez, M. (2009). El desarrollo de competencias en la Universidad a través del Aprendizaje y Servicio Solidario. Revista Interamericana de Educación y Democracia, 2(1), 56-77. Hemendik hartua: https://www .curricular.info.ve/Docu/MESAS/Folgueiras.pdf

Folgueiras, P., Luna, E. \& Puig, G. (2013). Aprendizaje y servicio: estudio del grado de satisfacción de estudiantes universitarios. Revista de Educación, 362, 159-185. Hemendik hartua: http://www .revistaeducacion.educacion.es/doi/362_157.pdf

Freire, P. (1971). La educación como práctica de la libertad. Bogotá: Siglo XXI.

Furco, A. (2001). Advancing service learning at research universities. In M. Canada \& B.W. Speck (Eds.), Developing and implementing service learning programs (pp.67-78). San Francisco: Jossey-Bass Publishers.

Gezuraga, M. (2014). El aprendizaje servicio (A-S) en la Universidad del País Vasco (UPV/EHU). En el camino hacia su institucionalización. UNED-eko Tesi Doktorala.

Gezuraga, M. (2017). El Aprendizaje-Servicio y su Contribución a la Función de Extensión Universitaria. Desarrollo en la Universidad del País Vasco (UPV/ EHU). Revista Electrónica Iberoamericana Sobre Calidad, Eficacia y Cambio en Educación, 15(1), 5-18.

González, M. (2011). El practicum ene 1 aprendizaje de la profesión docente. Revista de Educación, 354, 47-70.

Gysling, J. (1992). Profesores: un Análisis de su Identidad Social. Santiago de Chile: Centro de Investigación y Desarrollo de la Educación (CIDE).

Kolb, D. A. (1984). Experiential learning: experience as the source of learning and development. Englewood Cliffs, NJ: Prentice Hall. 
Krippendorff, K. (1980). Content Analysis. An Introduction to Its Methodology. Beverly Hills, CA: Sage.

López-de-Arana, E., Rekondo, Z. \& Salegi, E. (2013). Ziurgabeak diren testuinguruen erabilera Haur Hezkuntza Graduko ikasleen formazioan. Ikastaria. 19, 285-310.

Lorenzo, V. \& Matellanes, B. (2013). Desarrollo y evaluación de competencias psicosociales en estudiantes universitarios a través de un programa de Aprendizaje-Servicio. Revista Internacional de Educación para la Justicia Social, 2(2), 155-176.

Luna, F. \& Jaussi, M. L. (1998). CP Ramón Bajo de Vitoria-Gasteiz. Una Comunidad de Aprendizaje. Cuadernos de Pedagogía, 270, 36-44. Hemendik hartua: https://pnvgasteiz.files.wordpress.com/2010/11/comunidad-de-aprendizaje-ramon-bajo.pdf

Maynes, N., Hatt, B. \& Wideman, R. (2013). Service Learning as a Practicum Experience in a Pre-Service Education Program. Canadian Journal of Higher Education, 43, 80-99.

McIlrath, L. (Coord.)., Aramburuzabala, P., Opazo, H., Tuytschaever, G., Stark, W., Mikelic, N., Meijs, L. C. P. M., Mažeikiene, N., Zani, B., Vargas-Moniz, M., Millican, J., Northmore, S., Altenburger, R., De Bruyn, K., Hopia, A., Pessi., A. B., Grönlund., H. \& Maas, S. (2016). Europe Engage Survey of Civic Engagement \& Service-Learning Activities within the Partner Universities. Hemendik hartua: https://europeengagedotorg.files.wordpress.com/2016/04/ report-euen-mcilrath-et-al3.pdf

Mendía, R. (2012). El Aprendizaje-Servicio como una estrategia inclusiva para superar las barreras al aprendizaje y a la participación. Revista Educación Inclusiva 5(1), 71-82.

Nazio Batuen Batzar Nagusia (2015). 70/1 onartutako erresoluzioa. Gure mundua eraldatzea: 2030 Agenda, garapen jasangarrirako (Eusko Jaurlaritzak finantziatutako itzulpena). Hemendik hartua: http://www.unescoetxea.org/base/berriak.php?id_atala=1\&id_azpiatala=1\&hizk=en\&zer=orokorrean\&nor=1454

Pardo, M. \& Opazo, M. J. (2019). Resisting schoolification from the classroom. Exploring the professional identity of early childhood teachers in Chile. Cultura y Educación (online argitaratua). doi: https://doi.org/10.1080/11356405.2 018.1559490

Prieto, M. (2004). La construcción de la identidad profesional del docente: Un desafío permanente. Enfoques Educacionales, 6, 29-49.

Puig, J. M., Batlle, R. , Bosch, C., de la Cerda, M., Climent, T., Gijón, M., Graell, M., Martín, X., Muñoz, A., Palos, J., Rubio, L. \& Trilla, J. (2010). Aprendizaje Servicio (ApS). Educación y compromiso cívico. Barcelona: Graó.

Ramírez, M. T. \& Pizarro, B. (2005). Aprendizaje Servicio. Manual para docentes. Santiago de Chile: Dirección General Estudiantil de la Vicerrectoría Académica en la Pontificia Universidad Católica De Chile. Hemendik hartua: http://www.zerbikas.es/wp-content/uploads/2015/09/0403RAMapr.pdf

Rivas, J. I. (2012). Investigación biográfico-narrativa: el sujeto en el centro. Hemen: II Congreso Internacional sobre Aprendizaje Permanente. Competencias para una formación crítica: aprender a lo largo de la vida, celebrado del 21 al 23 de junio de 2012, en Castellón, organizado por la Universidad Jaume I de Castellón. Hemendik hartua: https://drive.google.com/file/d/1qzhvDDmn_ QxnHKaNAnro5fPIWnVx2Hca/view 
Rodgers, C. \& Scott, K. (2008). The development of the personal self and professional identity in learning to teach. Hemen: M. Cochran-Smith, S. FeimanNemser, J. McIntyre \& K. Demers (Ed.), Handbook of research on teacher education (732-755). New York, NY: Routledge.

Rosenberger, C. (2000). Beyond empathy: Developing critical consciousness through service learning. Hemen: C. R. O'Grady (Ed.), Integrating service learning and multicultural education in colleges and universities (23-43). Mahwah, NJ: Lawrence Erlbaum Associates.

Saltmarsh, J. (2005). The Civic Promise of Service Learning. Liberal Education, 91(2), 50-55. Hemendik hartua: https://files.eric.ed.gov/fulltext/EJ697354.pdf

Sigmon, R. L. (1979). Service-Learning: Three Principles. Synergist (National Center for Service-Learning), 8(1), 9-11. Hemendik hartua: https:// nsee.memberclicks.net/assets/docs/KnowledgeCenter/IntegratingExpEduc/ BooksReports $/ 55 . \% 20$ service\%20learning\%20three\%20principles.pdf

Strauss, A. \& Corbin, J. M. (1990). Basics of Qualitative Research: Grounded Theory Procedures and Techniques. Thousand Oaks, CA: Sage.

Tapia, M. N. (2006). Aprendizaje y Servicio Solidario en el sistema educativo y en las organizaciones juveniles. Ciudad Nueva: Buenos Aires.

Tedesco, J. C. (2000). Educar en la sociedad del conocimiento. Buenos Aires: Fondo de Cultura Económica.

Tejada, J. \& Ruíz, C. (2013). Significación del prácticum en la adquisición de competencias profesionales que permiten la transferencia de conocimiento a ámbitos propios de la acción docente. Profesorado, Revista de Currículum y Formación del Profesorado, 17(3), 91-110.

Vahasantanen, K. \& Billet, S. (2008). Negotiating professional identity: Vocational teachers' personal strategies in a reform contex. Hemen: S. Billett, C. Harteis \& A. Eteläpelto (Ed.), Emerging perspectives of workplace learning (pp. 35-49). Rotterdam: Sense Publishers.

Keen, C. H. \& Pease, H. A. (2016). The role of service-learning and mentoring in the early career development of a research methodologist. The Qualitative Report, 21(1), 117-126. Retrieved from https://search.proquest.com/docview/177 6143714 ? accountid $=17248$

Zhang, G., Zeller, N., Griffith, R., Metcalf, D., Williams, J., Shea, C. \& Misulis, K. (2011). Using the Context, Input, Process, and Product Evaluation Model (CIPP) as a Comprehensive Framework to Guide the Planning, Implementation, and Assessment of Service-learning Programs. Journal of Higher Education Outreach and Engagement, 15(4), 57-83. 